\title{
Globalization, The Financial Crisis \\ and Petty Production in India's Socially Regulated \\ Informal Economy
}

\author{
Barbara Harriss-White \\ Oxford University
}

\begin{abstract}
ABSRACT
This essay explores theoretical and practical problems arising from the impact of liberalization/globalization and its latest crisis on India's informal economy - heavily populated by petty commodity producers (PCP) and petty traders. Its theoretical focus is the distinction between PCP and 'labour' more generally because it is now common practice theoretically to elide the two kinds of work. Reviewing field material it focuses on two aspects of India's informal economy - the persistence of small firms and their regulation by social institutions rather than by the state. These social institutions express identity as well as class. Its practical concerns are on the impact of globalization on PCP and labour in global value chains and the effects of the financial crisis on PCP in India's informal economy.
\end{abstract}

KEY WORDS

financial crisis, global value chains, informal economy, labour, petty production

\section{Introduction}

This essay explores some theoretical and practical problems arising from the impact of liberalization/globalization and its latest crisis on India's informal economy heavily populated by petty commodity producers and petty traders (henceforth PCP). Its theoretical focus is the distinction between PCP and 'labour' more generally because it is now common practice theoretically to elide the two kinds of work. ${ }^{1}$ Reviewing field material, it focuses on two aspects of India's informal economy - the persistence of small firms and their regulation by social institutions rather than by the state. These social institutions express identity as well as class. The practical focus of this essay is on the impact of globalization, and the financial crisis on PCP in India.

India's informal economy includes entire industrial clusters making goods for export (metal-ware, machine tools, leather-ware, textiles and garments, tools and equipment, and some IT services). In 1999, over 40 percent of India's manufactured exports were estimated to have originated in unregistered workshops and 'gulleys' (Sinha et al 1999). The informal economy includes the black economy, focussed on retail inventory, construction and real estate, the film industry, precious metals and the products of tax evasion (Roy 1996). Estimated at 40 percent of GDP ten years ago 
(Kumar 1999; 2005) and growing, India's black economy is not marginal or confined to socially excluded people; it is central and involves prominent and socially powerful people too. The informal economy is not confined to services, but includes production and property rights protection as well as informal institutions of economic/'social' security (provision of help in time of need) - formal responsibilities of the state which it has all too often honoured in the breach.

The scale of PCP in India is a well established and comparatively well studied phenomenon. Two thirds of GDP comes from unregistered, informal activity. This proportion is growing rather than contracting, and accounts for over 90 percent of India's livelihoods. More than half of these livelihoods come from self employment - as much as one third of GDP - and 98 percent of self-employed livelihoods are in the informal economy (Kannan 2008: 8).

Development conceived as a transition from custom to contract is a project about changes in the relationship between the informal economy and the modern state. ${ }^{2}$ As a concept, the informal economy has survived much criticism precisely because it draws attention to the key issue of the state's enforcement capacity. ${ }^{3}$ In this light, the informal economy is as modern an element of capitalism as any other, where modern states, which possess the power of enforcement, actually choose not to exercise it in some sectors of the economy. PCP is not 'preserved', it is not a separate form of production, it is an outcome of capitalist relations and unable to be reproduced without capitalism.

Mushtaq Khan, interrogating the state's role in capitalist accumulation (2004), has argued not only that states have had to permit the existence of fuzzy, indistinct property rights in order for initial capital to be amassed for capitalist investment, but also that forms of extra-market accumulation, for which he deploys Marx's term 'primitive accumulation', co-exist durably with advanced forms. He is challenging classical political economists - Smith, Marx, Weber, Veblen, Schumpeter and other - who expected nonmarket forms of exchange to be destroyed by (respectively) the animal spirits released by markets, the struggles of wage labour against exploitation and illusion, the rationality of state bureaucracy and planning, the discipline of machines and technology and the dissolving force of education. ${ }^{4,5}$ They thought two aspects of such primitive economic exchange would lead to this result. First, small firms would be destroyed through competition from large firms exploiting economies of scale, or by the logic of centralization and concentration, or as a result of the historical process of creating a wage labour force. Second, 'forces for social inertia' in economic behaviour (Myrdal 1968 those he named were prescient - ethnicity and religion - though he omitted gender) would be dissolved by the 'common economic bonds uniting different groups' i.e. by class formation (Madan 1987, is quoting Nehru here).

But the informal economy persists in the era of globalized and advanced capitalism; its role changes, as do the roles of its key features of smallness of scale, and social - rather than state - regulation. ${ }^{6}$ These shifts have to be understood if we are to understand the impact of globalization on an economy like India's. 


\subsection{SMALL SIZE}

The informal economy rarely survives as peasant or artisan craft production. But small-scale forms of commodity production - together with generally overlooked petty trade and services - show a rugged capacity to survive misfortune, disaster and transformations of environment. They can be found alongside factory production all over the world, from small scale mining in Bolivia, through cosmetics and shoes in Nigeria, to rice in West Bengal and traders on Italian beaches. Furthermore, the law of one technology' does not hold either; in fact a range of technologies, contracts and organizational forms are employed simultaneously. While because of their numbers small firms and self-employment often appear superficially to embody the perfect competition of the textbooks; beneath the surface they are frequently found to bear a fractal resemblance to networked MNCs, in which oligopolies control a mass of small firms through credit, raw materials supplies and marketing outlets - a long established form of 'contract' production.

There is a wide range of product types, production conditions and social relations under which small-scale, unregistered production persists.

First, with reference to its internal dynamics, PCP is generally understood as a form of dependent 'disguised' labour - equally subordinated to, and subsumed under, capital as is wage labour. But it differs from wage labour in ways which cheapen it. Its logic can be expressed in two ways. In terms of marginalist economics, petty commodity production is possible past the point where the marginal product equals the wage. It is super-efficient. In terms of political economy, PCP permits the intensive exploitation of the entire family (including child labour) in sites hidden from scrutiny. Its dispersed locations make political organization difficult. Wages may not exist as either an alternative or a referent. As part of a set of household subsistence activities including food production PCP may subsidize industrial wages which may then explore levels below the reproduction cost of labour. It is super-exploitative.

Surplus is extracted through at least three markets in the forms of rent, interest and the terms of commodity exchange rather than through the wage-profit route of the labour market. Formal production, even with economies of scale, is not always able to out-compete such arrangements.

Second, with respect to relations with other fractions of capital, PCP may be incorporated into formal firms. The out-sourcing or subcontracting of (small-scale) elements of production can be an integral part of factory production, as can be insourcing' (where 'independent' petty producers bring their own machines and equipment into a factory not owned by them). Cost and risk may be shed from large firms through out-sourcing, in-sourcing, sub-contracting and home-working. Legal and social obligations to labour are offloaded.

Third, PCP is flexible - permitting the tying of firms at peak seasons through delayed and partial payments while shedding them at will. Using its small satellites, the hub firm can shed the capital and repair costs of equipment, working capital, bespoke services, and the need for infrastructure, and avoid scrutiny by state. It does not shed all supervision costs, since the finished product requires scrutiny (and often deductions are made from payments as a result). Through this flexibility PCP may subsidize permanent wage labour. 
Fourth, connections among producing units create interdependence between workers using their own means of production and petty capitalists. Clusters and industrial districts generate economies of collective organization and collective political 'voice', lowering the costs of information, skills acquisition, technical innovation and organizational flexibility, often theorized as being based on trust (Roman 2008; Basile 2008). Caste or ethnically stratified artisan clusters, locked into PCP by exploitative exchange relations, appear to express the institutional pre-conditions for flexibly specialized production but in practice are rarely able to escape 'low equilibrium' social organization and productivity (Cadene and Holstrom 1998).

Fifth, the state's relation to PCP is both ambivalent and contradictory simultaneously endorsing actions which destroy PCP, protect it, promote it and permit it through enforcement failures and neglect. ${ }^{7}$ First, the state destroys PCP by means such as physical eviction and by displacement as a result of promoting capital-biased technology. Second, it subsidizes and promotes the reproduction of small enterprises not through production but through whatever infrastructural and welfare/social sector interventions are aimed at sustaining the households involved in it. Third the state promotes production by small enterprises not just with self-help groups and by permitting a mass of more or less experimental micro finance arrangements but also by condoning and not policing the onward lending of 'formal' credit on unregulated terms and conditions which prevent the borrowers from accumulating. Fourth, to prevent mass unemployment, widespread malnutrition, etc, it implements - more or less exiguously policies that prevent the destruction of small scale production, trade and services. In so doing it creates small enterprises it cannot regulate and incidentally also restricts accumulation. Its infrastructural responsibilities to employers may be avoided if production is outsourced to petty producers. It does not enforce laws through which the super-exploitative advantage of petty production would be abolished. Nor does it enforce fiscal measures that would threaten through taxation the nutrient-bed of petty production. So PCP also thrives through neglect because the small individual capitals involved do not accumulate sufficiently for the revenue from tax to outweigh the costs of its collection.

The state implicated in this account of PCP is one which may have had 'bourgeois revolution' as its project but which has actually created a petit bourgeois revolution for which it does not have a coherent project other than trickle down. ${ }^{8}$

Clearly, as has been concluded elsewhere, there are 'many phenomenal forms of capital' (Cook and Binford 1986, p23). Although this essay focuses on PCP, activity in the informal economy is not all petty. PCP may hire in wage labour and invest productively when possible and needed - so moving between PCP and petty capitalism. While petty commodity production and trade dominate livelihoods in statistical terms, not all subcontracting in the informal economy is to PCP enterprise. Informal activity also thrives inside large and complex formal, corporate, state and para-statal organizations. The informal economy is a differentiated site of accumulation where casual wage labour forces approaching a thousand unregistered workers per firm have been encountered in fieldwork. Although the poor are in the informal economy not all in the informal economy are poor. 
When the state supplies neither the collective preconditions for competition nor undertakes income redistribution, institutional 'substitutes', guilds, trade associations and other kinds of collective action take on many of these functions. They facilitate economic activity, but at the same time they constrain it because while they are necessary, they are all more or less arbitrary, incomplete and exclusionary. These institutions are real and no policy blind to their existence is likely to achieve its intended results - at least without the distortions needed to work through such institutions and organizations.

\subsection{SOCIAL FORMS OF REGULATION}

The Indian state has a well-specified framework of law regulating the economy. But law enforcement requires a set of institutions providing adjudication and justice, allowing claims for the redress of wrongs, punishment and the prevention of recidivism (McBarnet 2003; Stern 2006). The absence, or malfunctioning, of any one of these mechanisms makes law enforcement problematic or impossible. Lack of enforcement capacity, and/or complicitous non-enforcement, create cultures of non-compliance in which the law is irrelevant. Both the state and the economy become socially regulated, with the degree of enforcement of regulative law defining the extent of the informal economy. Processes of selective enforcement likewise are socially embedded and 'informalized'.?

But enforcing informal, social regulations requires the same institutional preconditions as law enforcement and will confront as many kinds of deviance as there are social rules to break. Control is achieved with methods that are illegal but 'customary' - ranging from threats, through social sanctions, ostracism and the seizure of documents to the use of physical force (Shapland and Ponsaers 2007). We know relatively little about practices ensuring enforcement and institutional continuity, particularly when threatened with external changes and with acts of 'agency' and of contention experienced by others as acts of deviance and to be resisted. How institutions police themselves; how cultures and subcultures of non-compliance develop; how they affect the wage-profit relationship, tax revenues and the selective enforcement of state law; all these are important matters needing more research.

What we know is that in the absence of state regulation, the informal sector is not unregulated or chaotic. Forms of social regulation bring order and stability to a rich complexity of forms and scales of production, ownership, contract and exchange relations. ${ }^{10}$ Aspects of identity are reworked to become regulators of the non-state regulated economy. They structure and stabilize accumulation. They may also pervade the state (Khalidi 2008). Age/generation, gender, caste, ethnicity, religion and place constitute regulative forces all of which play a role in - and disguise, delay but do not halt - class formation. ${ }^{11}$ Ethnicity and caste, for instance, persistently structure recruitment and occupation. Caste and ethnicity lie behind the guild-like business associations which are obstacles to the mobility of capital and labour and which were also confidently predicted to disappear with modern market forces. These small units of accountability and of collective action may police entry, organize apprenticeships, calibrate weights and measures, regulate derived markets (labour, porters, transport), adjudicate disputes, guarantee livelihoods, respond to individual or collective misfortune and accumulate the 
funds necessary to represent the interests of market actors, shape the way policy is implemented and collectively evade tax. In this effectively corporatist project, the interests of labour are conspicuous by their absence (Basile and Harriss-White 2000; Basile 2008).

It is hard to destroy such institutional arrangements, so state and social forms of regulation co-exist and inter-penetrate. The dissolving forces of modernity are at work, capital and labour do become more mobile, labour forces do become more cosmopolitan, old institutions are indeed destroyed and new ones created, but the opposite also occurs at the same time and in close spatial proximity (Parry 2007); so-called archaic forms of regulation co-exist with modern ones and adapt, rework themselves and intensify. Some have the capacity to persist as regulative forces, almost unchanged by modernity.

Institutional change therefore involves four processes: creation, destruction, persistence and adaptation/reworking. These simultaneous processes are not easy to theorize, but their reality must nonetheless be a central focus of any useful social science of development. So in the second half of this essay, we turn to the relationships between liberalization, globalization and crisis on the one hand and the persistent structure of socially regulated petty production in India's informal economy, on the other. For this we use case studies and secondary literature.

\section{Trade Liberalization, Globalization and Petty Production in India}

In Globalization and Insecurity (Harriss-White 2002), we examined specific aspects of globalization (finance, manufacturing, weapons as a case in point, trade, labour, social security etc) and asked how globalization created new insecurities and 'what was being done' about them. Eclipsed by security research after 9/11, the project nonetheless pointed to many causes of economic insecurity for capital as well as labour, and to the fact that rather little was being done in response that did not exacerbate these insecurities. It revealed a parallel set of relations of global informality in finance, trade and manufacturing, in which PCP compete with economies of scale in global value chains. These have also generated insecurity in the formal global system, with even less being done to protect against these informal and sometimes criminal processes. Globalized capital has reproduced itself recklessly and, even before the Wall Street system's collapse, the security and working conditions of the world's restructured division of labour had not unambiguously improved.

In India, globalization has encouraged export-led industrialization in certain manufactured goods and services which have also been stimulated by imported technological upgrades. Thirty-four sectors of India's ISI core have been opened up in this way (Nath 2008: 539). Less foreign capital and even less FDI than was predicted has materialized - it is rather that some investment has been re-allocated from the informal to the formal ('modern', 'tradeable') part of the economy in which forces of centralization and concentration are operating (Ghose 2008). Some fractions of Indian capital have embarked on mergers and acquisitions in Europe and the USA (Sardar 2008). Simultaneously under liberalization, capital-biased technology in the formal sector displaces labour into the informal economy in which production is decentralized (Sinha and Adam 2007). Nath notes UN agencies' dignifying this process by classifying informal 
workers as 'own account'/'independent producers' (2008: 539). As well as dignifying labour, they are trying to distinguish PCP from wage-work. In fact, these formalinformal, wage-work-PCP migrations put downward pressure on labour productivity and wages in the informal economy (where productivity is now a third that of formal sector workers). They stall the process of improvement of conditions of production (Ghose 2008: 503-504). ${ }^{12}$ The 2006 NCEUS report on Social Security for Unorganized Workers records that in 2005, nearly 80 percent of workers subsisted on Rs 20 per day or less, without rights to work, at work or to social security.

What is happening? Official data on employment is often hard to interpret, a given task occupying varying class and status positions and even varying in its classification (Huws 2007). Scholars of globalization and employment/labour use official statistics which conflate wage work and self employment (occasionally expressing regret for doing so). They make theoretical arguments assuming that they are mutually substitutable. But the empirical case-study evidence we have shows that this assumption is wrong.

The case-study literature traces the emergence of global value chains (GVCs) which structure an ever more complex division of tasks and add stages and value to the production of raw materials in developing countries. GVCs also develop internationally from existing 'artisan' clusters. A variety of organizational technologies sit side by side in GVCs within a given sector (Vijay 2008: 5-10). Both processes of emergence require the construction and exploitation of competitive advantages in labour costs. They replace horizontal competition in transactions at each link in the chain by tight vertical coordination in production. MNCs redefine core competences to focus on innovation, product strategy, marketing and the highest value-creating processes in manufacturing and services. They divest direct ownership over non core functions such as services and volume production. Codification, standardization and computer-aided design have enabled control over GVC logistics (Vijay 2008; Huws 2007). Tightly controlled 'network governance' requires shedding risk and cost wherever incentives to work can be self-driven - key to which is the shedding of wage work, or attempting never to assume the costs of a wage-labour force in the first place.

The significance of the degrees of coercion, dependence, autonomy and freedom of PCP is debated. So are the legitimate and illegitimate reasons for the process of global informalization through lay-offs and the extinction of formal employment in advanced capitalist countries, and in the formal sector of developing ones. Modes of exploitation are also seen to become more complex in GVCs. While in agricultural production, for instance, rent, surplus value, interest and exchange have always co-existed, now such 'horizontal' co-existence is complicated by the 'vertical' co-existence of multiple modes of appropriation of surplus.

In an era when 'human development' has regained currency as an end as well as a means, the value chains literature at least reasserts a concept of development as a process of industrialization (though a development model of industrialization for 'human development' remains unelaborated). The GVC literature, however, reduces development to the successful creation and protection of rents inside GVCs (Kaplinsky and Morris 2000) or even to the mere integration of local production into GVCs (Messadri 2008: 604). In this politically unimaginative 'developmental' process of incorporation, rent 
protection and non-competitive alliances or monopolies, distributive shares in value chains (the relation of wage shares (or returns to labour) to profit) are being tilted toward profit and away from 'labour'. ${ }^{13}$ Human development suffers. Although increases in production can take place without great concentrations of capital, in the current era decentralized production clearly fulfils the accumulation objectives of large firms controlling the strategic GVC links. The collusion between PCP and wage labour that would be necessary to resist this shift is far easier said than done. ${ }^{14}$

\subsection{SMALL SIZE}

In the NS Survey $61^{\text {st }}$ round for 2004-5, two thirds of jobs in India were found to be self- employment. 'One of the most significant employment trends is the rise in self employment ... (with)... a surge in trade, commerce, private business, outsourcing, subcontracting, home based working and provision of services' in sectors such as food processing, beverages, textiles, garments, footwear, catering, lace, embroidery, bidi and agarbathi making, street vending, transport and domestic services (Nath 2008: 539). At the same time insecure contract labour has doubled from 12 percent of employment in 1980 to 25 percent in 2004, including in hi-tech science-based industries like pharmaceuticals and chemicals - apparently displacing permanent salaried employment, rather than PCP (Neethi 2008: 565). GVCs evidently incorporate both of the main categories of insecure labour in the informal economy: wage work and PCP.

Two questions may be asked of this dual trend. First, how does PCP differ from casual wage labour in GVCs? There is no doubt a conceptual grey area between PCP and wage labour, since much wage work requires the labourer to own certain equipment (e.g. head-loading baskets and hods in the construction industry, knives in forest work, mamoties/hoes for agricultural labour, needles and sewing machines for embroidery and garment making etc). There is certainly also some volatility and substitutability between the two forms of work (Papola 2008). PCP is distinguished by the combination of ownership of the means of production, self/family exploitation and exploitation through several markets other than that for labour. Singh and Sapra's multi-sited field research on the liberalization of garments GVCs provides empirical evidence for the following tentative conclusions about the distinguishing features of PCP in GVC: PCP reduces but does not shed all supervision or telemediation costs associated with wage labour management; it reduces fixed and variable costs of equipment and working capital; PCP may avoid the need for in-house vertical integration; it also enables production with nonwritten-records and verbal contracts and so avoids the costs of scrutiny by state; it reduces employers' needs for infrastructure; it sheds statutory obligations to labour under the factories acts and exploits child labour (Singh and Sapra 2007: 83-84; also confirmed by Kanbur and Jhabvala's gendered analysis 2004, 304). All these represent actual or potential cost advantages of PCP on own premises over casual wage labour using the equipment of others.

The second question is why, if PCP can cost even less than the wage labour it may contribute to subsidizing, do wage labour and PCP co-exist in the informal economy? Studies of the gendering of productivity in sex-sequenced and sex-segregated production suggest that to answer this question we should distinguish three kinds of co- 
existence in the relations between PCP and wage labour. They are ignored or confused in the literature on GVCs, clusters and industrial districts. The first is 'process-sequential' in which PCP and wage are deployed at different stages in a GVC; the second is 'processsegregated' in which certain sectors of the informal economy are populated by PCP and others by wage work; the third is 'process-integrated' in which PCP and factory production using wage labour are mixed at all stages of a GVC.

Comparative field economic research on silk weaving and garment-making suggests that conditions favouring process sequence include modularized stages of production where self-exploitation is possible without supervision, where equipment is not lumpy, where high skill/ craft apprenticeships are necessary to entry, where risks of opportunism (e,g, adulteration) are low, where production does not require unmediated access to market information, co-ordination costs are low, there is no need for continuous relationships with the next buyer, where reputation policies incentives and where the costs of codification and standardization argued necessary for decentralized production can be avoided. These conditions certainly characterize sari weaving, buttonholing and stitching, dyeing, bleaching, label making and gem cutting ${ }^{15}$ - also transport, and services such as cleaning. And while tiers of subcontractors may be controlled by merchants'/commercial capital, large economic spaces also exist for the proliferation of small intermediators, agents and traders.

Process segregation is found in social structures and sectors generating small capitals, where firms are held tightly in exchange relations and/or regulative environments which prevent savings, investment and accumulation, and where occupations are regulated by social status groups and still firmly mapped onto either rural or urban sites. Process segregation is a common attribute of bespoke production and services. It is also compatible with seasonal non-farm production as income supplements in agrarian society and with short VCs for local demand. A case in point is the remote mountain state of Arunachal Pradesh, where the richly varied local craft production is done for use as well as exchange and in multi-skilled households not specialized in artisan occupation groups. ${ }^{16}$ Small-scale businesses are commercializing craft under restricted economic citizenship and a subsistence-remittance economy. ${ }^{17}$ By contrast, craft production and petty trade has all but vanished from the commercialized and remittancebased hill economy of the state of Uttarakhand, due north of New Delhi.

In process-integrated GVCs, PCP and wage labour compete at every stage of the value chain. This is the case in garment manufacturing in Tiruppur in S. India. The type and quality of the finished product affords no sign of the conditions under which it was produced, no variation in quality due to the organization of production. Sometimes there is even little difference in technology between the two forms of production. Economies of scale in Taylorist production co-exist with no economies of scale, self exploitation and - in some cases - the development of collective capabilities. Process integration is found under conditions of easy entry, versatile and unspecific assets, low fixed costs, wide variation in the conditions of finance and raw materials supply under which production is possible and variation in demand for specific processes and competences. Some PCP is of course spurious, where physical production units are decentralized but are masking a concentration of economic control. In such instances its 'development' is pre-emptive, to avoid the costs of regulatory enforcement. In the life 
cycle of a product/commodity, PCP can perform a variety of roles in all three types of niched co-existence with wage labour.

With these distinctions in mind, we can evaluate case material to trace the impact of globalization on PCP.

India's GVC for garments has never been a regulatory free-for-all, export production being regulated by the Apparel Export Promotion Council. From 19742005 the global Multi Fibre Agreement imposed quotas on exports and formalized informal GVCs in many DCs, not least in India. From 1985 restrictions on the organization of the garment sector were formally removed so as to increase the flexibility of the 'labour market' (Singh and Sapra 2007: 45). However since in practice preliberalization production was structured pre-emptively around the formal exclusion of small scale handloom and power loom production from the provisions of the Factories Acts, the pressure of global regulative regimes on local liberalization merely intensified existing tendencies to outsource production to small firms. The Indian segments of these GVCs are 'layered and complex' (Singh and Sapra 2007: 49). Quite commonly, owners of formal sector factories also own unregistered firms, split off to obtain benefits from small industry policy (Singh and Sapra 2007: 83).

In the process-integrated knitwear cluster of Tiruppur, thousands of small workshops co-exist with mechanized factories. Between 25 percent and 100 percent of factory production is outsourced. Knitwear and garments in Tiruppur are dominated by intertwined commercial and manufacturing capital which control a cluster of networked, flexibly-specialized PCP. The process of labour-displacing mechanization co-exists with labour-intensive resistance to technical change. Until now, this flexibility has been geared to the global expansion of markets and to increasing velocity in the peaks and troughs of fashion orders (Singh and Sapra 2007: 83).

By contrast in 2005, the low-end garments clusters in and around Delhi are process-sequenced, providing about 250,000 livelihoods in a range of firm-sizes. Over 80 percent of the firms were unregistered, employing increasing numbers of male migrant wage workers, 'in-contracted' as gangs organized by, and accountable to, a layer of contractors inside the factories who were also subcontracting to PCP. In Messadri's account, subcontracting is increasingly confined to the craft production of embroiderers in rural artisanal clusters at some distance from - but integrated with - the metropolitan industrial cluster. PCP has proved unable to increase its productivity through upgrading technology. Globalization here is having an opposite impact on the organization of production from its effect in Tiruppur and pressure for cost-cutting with quality improvement in the low-price segment has resulted in a reduction in PCP and a shift to in-factory gangs of contract labour (Messadri 2008; Singh and Sapra 2007).

Meanwhile in the Moradabad metal work cluster studied by Ruthven, several kinds of value chain for final markets in Europe have developed side by side, with wage work interleaved with (sub-sub-contracted) outsourcing and even in-sourcing (involving workers' own machines re-sited inside factory premises). While most GVCs in Moradabad are process-sequenced, some are process-integrated. PCP is valued by employers for its flexibility as a mechanism of cost minimization when orders are unpredictable and peaked. It is valued by workers for the social independence it provides, the opportunity it gives to express identity through values derived from religion, and the 
liberty to choose between several manufacturers and merchants rather than relying on a single employer. The struggle between forms of production is seen to be the product of institutions and relationships operating outside the workplace as well as in it. The household is a site of production for exchange as well as reproduction and production for use (Ruthven 2008).

The case material shows that the impact of globalization on PCP is highly differentiated and specific to different GVCs. In GVCs, a given commodity may be produced under process-sequenced and process-integrated combinations of PCP and wage labour.

\subsection{SOCIAL REGULATION}

Social structure and relations based in identity which transcend the economy play fundamental regulatory roles in informal market exchange. Changes to their economic regulatory role may derive from agency or deviance outside the economy as well as inside it.

In Tiruppur for instance, sub-contracting relations are cemented through tight networks of caste. The local dominant agrarian caste has played an controlling role throughout the history of development of this cluster - sufficient to block outsiders from entry. The subordination of women means that even for similar tasks (tailoring and cutting) women earn less than men. Evidently wages are shaped by patriarchal norms rather than by gender differentials in productivity. Formal unions (once strong) have atrophied and been replaced by corporatized control over production conditions by business and caste associations (Singh and Sapra 2007: 45, 92-97).

It is certainly possible for regional 'outsiders' to enter; but successful entrants have had to occupy particular niches - on a larger scale, with imported wage labour forces and vertically integrated production processes. As 'deviants' they faced hostile opposition from an alliance of trades unions and local exporters and have had to cede to local informal labour contractors and use local casual labour.

The production of Delhi's low-value garments is regulated through groups of migrants recruited on the basis of region, age and domestic status (without families) and gender (men migrating without women). Work conditions are so poor that workshops are used as dormitories: productive and socially reproductive spaces are one and the same (Messadri 2008: 612 -613). The workings of these social institutions 'fill the regulatory gaps opened by neo-liberal policies', are incorporated into the cycle of capitalist production, and become necessary to global 'capitalist architecture' (Messadri 2008: 603).

As well as being stratified by gender (women being secluded) and by HinduMuslim religious identities, the Moradabad metalwork cluster is regulated by the voluntary codes of conduct demanded by foreign buyers (and consumers). Imported from abroad, confined to organized manufacturing, and designed to improve working conditions, these codes have developed in India since the turn of this century. Ruthven finds them confined to suburban factories, and only where a third party audit or a company inspectorate is provided. Most suppliers seek to operate outside the new voluntary codes. (Ruthven 2008, ch 3; see also Singh and Sapra 2007: 71). 
In the light of such social regulatory practices the common assumption by labour economists about the substitutability of PCP and wage labour is an open question.

In these case studies all four trajectories of institutional change (persistence, creation, destruction and adaptation) have been observed. Institutional continuity characterizes gender relations. Women are incorporated into the labour market on persistently disadvantageous terms. They are often reported to earn less than minimum wages, or their equivalent in returns to PCP. The lengthening of the working day, the absence of crèches or holidays, the classification of women as trainees on lower pay (a trick not confined to women but very common for them) all attest to a prevalent deterioration in women's working conditions (Unni 2008; Chatterjee 2008). The field material also indicates a range of newly created institutions - in particular in new contractual forms such as in-sourcing, in-contracting and the rapid spread of casualized, piece-rate, contract labour. The operation of GVCs is evidently able to destroy established contractual forms such as permanent, salaried labour and to create conditions which threaten or destroy trades unions - in other words, to put the conventional sequence of 'development' into reverse. But older institutions are also reworked and adapted to suit the purposes of accumulation: caste is formalized into regulative trade associations; region of origin is important in the organization of both capital and labour. Instituted non-state behaviour also shows a capacity to police itself against deviance: outsiders to Tiruppur for instance had their labour relations policed into local conformity. In the material summarized here, both PCP and wage labour are regulated through identity. In the informal sector, the economics of identity slows class formation and fragments labour.

These different trajectories of institutional change reflect the reproduction of workers in oppressive conditions in the informal sector. Sustaining this institutional restructuring is the state - operating beyond its own direct reach. Its response to globalization has been described by Ahluwalia (2008) as 'gradualist'. ${ }^{18}$ Gradualism arrogates to the state the power of selectivity in its welcome to FDI. ${ }^{19}$ The state has created the conditions in which capital is being concentrated but production is being decentralized in the socially regulated informal economy. In so doing, the state is selectively not intervening as a matter of (undeclared) policy.

\section{The Financial Crisis and Indian Petty Production}

At time of writing in early-mid 2009, there are four reasons for this part of the essay to be the most speculative. First, the crisis is developing in India and is expected by the Planning Commission to hit the economy with full force only later in 2009-10. Second, mainstream economics failed either to predict the crisis or to understand its prime movers. An array of views has been tabled ranging from [to name but a few] contagion from sub prime lending, through business cycle explanations, misconceived expectations, mismanagement of reserves, Hayekian instability, to moral hazard in the financial sector, incompetence and stupidity among policy-makers. ${ }^{20}$ Third, the science of economics has proved unable to ascertain either the likely extent of the slowdown or its impact on labour, a failure linked to the failure to understand the dynamics of the informal economy. Fourth, since the analyses of economists of labour do not generally 
distinguish between wage labour and 'self employment', PCP, the largest single employment category in the economy and the focus of this essay, goes almost entirely unnoticed.

Given the openly acknowledged failure of economics, we use the explanation for the financial crisis given by the international political economist Peter Gowan as a backcloth to the analysis of its impact on India's informal economy. Gowan situates the most destructive speculative bubble - in US housing - in a regular series that have been necessary to the new Wall Street financial system. The latter is dominated by an oligopoly of banks and their satellites which has been permitted to speculate on future assets and collateralized debts. ${ }^{21}$ Only a few Indian banks have a direct exposure to the financial collapse triggered by the new Wall Street system and its satellites. But while the Indian financial system is relatively well capitalized, it is suffering from the seizure in lending, outflows from the stock market and shrunken flows of remittances. ${ }^{22}$

The major impact, however, is being felt in the real economy where oil and food price instability was already generating inflation and slowing corporate investment. The Planning Commission is rightly concerned with the fact that its predicted 9-11 percent growth rate will be reduced down to 6 percent or even 5 percent - in 2009-10. ${ }^{23}$ This will 'hurt labour' but the extent, sectors, sequencing and duration of the damage are unknown. There is no theory of the likely impact on the unprotected informal economy where the reduction in growth rates mean livelihood losses.

Demand for exports is predicted to drop by anywhere from 10 to 40 percent during 2009 and IT exports, already under pressure in 2008, are expected to be badly hit (CLSA 2009). The manufacturing growth rate halved from November 2007 to 2008 (GOI 2009). Lack of export credit is regressively hitting the smallest export firms in a disproportionate way while the depreciation of the Rupee hits imported components. India's exports are relatively labour intensive (Sardar 2008) - textiles, handloom garments, leather, gems and jewellery, metalware, carpets, agricultural products (spices, basmati rice and sea food) together with IT/BPO services. By December, 2008, 100,000 jobs were known to have been lost in the diamond industry in Surat and 750,000 in power loom weaving (Alagh 2008). A survey of eleven states in October-December 2008 recorded significant drops in capacity in the automobile, metals and export industries with about 500,000 job losses in the automobile, transport and gem/jewellery sectors. The rate of job losses in the informal sector ('contract work') is estimated to be six times greater than in the formal sector (GOI, 2009). WIEGO's responsive research showed a rapid and dramatic drop in demand and prices for recyclable waste from the informal economy - metals, cloth, plastics and glass - more insecurity in contracts and greater delays in payment in informal textiles and garments production and reductions in days worked and wage rates in the construction industry. ${ }^{24}$ Field research under-way in Chennai shows that the multiplier of the decline in IT exports reduces demand and finance for construction, demand for auto- and domestic services, street vending, laundry and ready made food supplies (Penny Vera Sanso, personal communication, 2009).

Earlier research already cited showed that the incorporation of PCP into GVC has not necessarily produced gains either for PCP or wage workers. There is also no single, let alone easily modelable way in which GVCs have responsed to previous changes in the market or the policy environment (Harriss-White and Sinha 2007: 7). So it is to 
be expected that a similar complexity - and ingenuity by both capital and labour - will characterize responses to the crisis.

What will be the role of PCP in this crisis? Small producers are easily disposed of by employers but so too is casual labour, especially female casual labour. ${ }^{25}$ The three modes of insertion of PCP identified earlier will structure the crisis relationship. Since process-segmented sectors of the economy (where PCP is prevalent) involve basic wage goods demand for which is income-inelastic, PCP will survive there. In processsequenced GVCs, both wage labour and PCP will be affected by reductions in foreign demand. But in process-mixed/integrated forms of GVCs, will wage labour be laid off first or PCP? Theoretically wage labour is less divisible than PCP - though recent changes in contracts aim to make it more flexibly exploitable (through piece rates and contract labour rather than time/day rates). That wage labour is more easily organized to resist layoffs than is scattered PCP will encourage employers to dismiss it earliest (Huws 2003). Scale economies evaporate under reduced demand, whereas PCP does not depend on them. If, under PCP, 'super-efficient' labour works until its marginal product approaches zero, and 'super-exploited' labour intensifies its own oppression compared with wagelabour, then reducing demand will first increase the marginal product of labour before lowering it, while total returns to the household of self-employed workers will drop throughout this process of contraction. Below the point where the marginal product of work is equal under both forms of production, wage work will not be an alternative. So the informal economy might witness some reversion to non-market production logics. Further, since the mode of exploitation of PCP is not through the wage but through prices, rent and interest, exploitation can be intensified through exchange relations on several markets whereas labour is exploited only on one.

These arguments suggest that PCP may well be more 'resilient' and able to 'bear shock' - and to be exploited in more oppressive ways - than wage labour.

Changes in the economy are bound to have far-reaching effects on social and political relations outside it. ${ }^{26}$ Reduced returns and incomes will put stresses on household budgets and gendered relations of social reproduction. Women's unpaid work is certain to increase, as unemployment rises, household incomes fall and labour and production for use is substituted for purchased goods. The extent to which this substitution is possible also depends on the availability of free resources and common property rights to resources to gather and glean. This may be easier in rural sites than urban ones. The retreat of the state has also triggered the substitution of private expenditure for former meagrely-provided public goods and services such as education and health care. The state will struggle to maintain subsistence guarantees, the costs of which will rise. So households will be left with reduced incomes and greater expenditure needs; the impact greatest on the most vulnerable. In such conditions we can expect not just the persistence - even the proliferation - of PCP plus the persistence of decentralization by large firms (Vijay 2008), but also the vigorous social policing of livelihoods in sectors producing basic wage goods; plus attempts to eject from such sectors workers who are recent entrants with 'deviant' social identities; and a marked strengthening of identity as a regulator of the economy. 


\section{Pro-labour Responses and Their Politics}

This essay has explored globalization and the persistence of what many consider 'pre-modern forms' of labour organization at the heart of the modern Indian informal economy. Self employment/petty commodity production has been distinguished from wage-work on the one hand and petty capitalism on the other - with both of which PCP may elide. When it comes to the juggernaut of the responses of the state and organized labour however, such distinctions are mostly ignored; and the argument that PCP is wage labour in disguise, or even 'disguisedly unemployed' and thus a reserve army of sorts ${ }^{27}$ becomes the political basis for the state's reaction.

In this final section first we summarize the recent responses to globalization, then the 'normative' responses to the economic crisis.

\subsection{THE CURRENT 'LABOURIST’ RESPONSE TO GLOBALIZATION}

The return of Congress in 2004 testified to voters' dissatisfaction with both the politics of Hindu nationalism and the failure of the reforms to improve economic and social conditions in the informal economy. But rather than enforce the enabling laws and existing legal structure protecting labour at work and rather than spread basic social security $^{28}$, a specific commitment was made to a new 'common minimum programme' for workers. Sufficient time has elapsed for its progress to be evaluated. According to the National Commission for Enterprises in the Unorganized Sector (NCEUS 2008) its components have suffered systematic under-funding, delays and corruption: the historic achievement of the National Rural Employment Guarantee (in December 2005: 100 days' work per year for people below the poverty line) is performing 'well below entitlement'; the Bharat Nirman project for rural infrastructure, irrigation and telephony suffers 'significant implementation lags'; rural electrification has 'major shortfalls'; water and drainage has used only 'half its budget'; and education, health and PDS food are under-funded. The NCEUS (2006) proposed bills for a social security safety net for urban and rural informal sector workers below the poverty line. Estimated at 0.5 percent GDP, they consisted of benefits for sickness, maternity, disability, breadwinner death and old age with a national fund to implement them. Two bills did indeed pass through Parliament, but in a watered down form and a non-compulsory enabling idiom, with ad hoc schemes, no national fund and no enforcement powers. ${ }^{29}$

At the same time a surge of activism and public interest litigation has created conditions in which a labourist and petty bourgeois agenda is publicly debated, developed and attacked. Civil society has organized around rights to work and to food, and some financial think-tanks are mobilizing around the right to (micro)finance.

\subsection{RESPONSES TO CRISIS: COMPOUNDING THE PROBLEM}

In Europe and North America as well as in India, the crisis has led to risky Keynesian fiscal expansion to stimulate the economy. ${ }^{30}$ Two kinds of response resonate to the tensions between social democracy and delinquent financial markets. The first involves a co-ordinated counter-cyclical expansion in state investment and expenditure to sustain the effective demand of victims of the crisis in the real economy, while the second is a fiscal expansion confined to underwriting finance capital. ${ }^{31}$ Globally the drift is 
towards the latter. In India the contradiction between the demands of the markets and those of democratic politics is reflected in the economic stimulus proposed respectively by the Ministry of Finance (MOF) and the NCEUS. The MOF recommends pumping sufficient liquidity into the banking system to enable bank credit to meet the expanded requirements of the economy (keeping in mind the contraction in credit from non-bank sources). It suggests authorizing additional plan expenditure, reducing central VAT, facilitating housing loans though bank interest rate management, boosting infrastructure finance through public-private partnerships, and supporting the credit needs of small and medium enterprises through credit etc. Banks are the key medium of implementation (MOF 2008). But banks are risk-averse and favour securities over commercial lending. Investments have stalled on a massive scale. Disbursements to the informal sector under 'priority sector' norms have been egregiously neglected (EPW Research Foundation 2009). Two recent government reports, Raghuram Rajan Committee's on 'Financial Sector Reforms' (2008), and the Reserve Bank of India's on the 'Trend and Progress of Banking in India' (2007) confirm that 41 percent of the adult Indian population live outside the ambit of banks altogether.

By contrast, the NCEUS (2008) documenting the mass poverty, low skills and negligible control over productive assets of informal sector workers - lumping PCP with wage-work - has clarified that it is those earning below Rs 20 per day who are rationed out of the banking sector, excluded from credit markets and thus untouched by the MoF's measures. The NCEUS stimulus (endorsed by the ILO) would strengthen the National Rural Employment Programme, expand local control, urbanize it and link it with complementary projects of state governments, introduce universal social protection etc. It has been largely ignored. It is said that there is no 'Plan B', ${ }^{32}$ but the NCEUS has Plan B. Were it implemented however, it would increase demand for wage goods, the production and prices of which have become unstable (Patnaik 2007; Ghosh 2009).

The supply side needs repair too. The NCEUS has proposed the creation of a national fund for the 'unorganized' sector, credit to small and marginal farmers, a massive infrastructure programme - rural and urban housing, water, watershed management, sanitation and waste management together with the under-funded 'human development trio' (food, education and health).

The NCEUS has attempted to outline a response specifically for PCP. This emphasizes the need to persevere with the improvement of industrial capabilities (to respond innovatively as sectors are under threat and to resuscitate growth poles [NCEUS 2009]). Skills, technology, credit, services and human development, all currently restricted to the formal sector, need investment (Kannan 2008).

\section{In Conclusion}

The majority of Indian livelihoods take the form of petty production, trade and services. In theory PCP is understood as disguised wage-labour, formally if not really subsumed to capital. We have reasoned that even if the latter is accurate, PCP is not disguised wage-labour. PCP is also theorized as disguised unemployment and the

manifestation of the 'reserve army'. We have argued here that this is not generally correct, even if PCP may sometime be performed on terms of oppression and distress. 
PCP is neither free nor unfree. It is not separated from the means of production, nor is it free of the restraints of self-ownership, not completely able to quit and seek alternatives. PCP is a relation of exploitation on three markets: property, money and commodity markets, using a range of modes of extraction of surplus. By contrast, the wage-labour relation involves exploitation on one market. ${ }^{33}$ At the same time petty producers and traders may move (seasonally) between PCP, wage-work and petty capitalism (employing others) and in these practices they are not unfree. Even so, PCP is not, as Partha Chatterjee wrote of it (2008), free as 'subjects with consent'. While free from state regulation and protection, PCP is regulated instead by social institutions forms of economic authority and domination made manifest through multiple social identities. Class politics is mediated through these institutions and also by corporatist guilds where it is often found that the interests of the smallest firms are pushed to the foot of the agenda. Social change takes three institutional forms: destruction, creation and adaptation - over and above persistence, which the evidence reveals rarely happens without a struggle between purposive action and punishable deviance.

In practice PCP is incorporated into global value chains in three ways: process segmentation, process sequence and process integration. Their existence conditions have been explored here. In process-integration, PCP competes directly with wage-labour, while throughout GVCs and because of its dispersed sites PCP is less easily organized than is wage labour. The distributive share in India's GVCs has moved towards profit and away from wages/returns to PCP.

PCP survives not as a failure of capitalism to transform pre-capitalist forms, but as a success of capitalist exploitation. If its persistence is a form of failure, it is due to the selective failure of the state to enforce its own laws regulating markets.

The Indian state is devoid of a coherent project for the PCP which this capitalist transformation has produced. In official labour statistics, PCP is hard to detect. At one and the same time the state destroys PCP (through eviction and displacement), protects it (through infrastructural and welfarist projects directed to conditions of its social reproduction), promotes it (through experiments with micro-finance) and perpetuates it through its neglect (perpetuating oppressive and exploitive conditions in the informal economy which prevent differentiation and accumulation).

The state's response to the crisis has been to keep the leading (financial) market players afloat ${ }^{34}$ at the expense of the vast impoverished majority in the informal sector where the state does not distinguish PCP from wage-labour. The conditions of both will deteriorate as growth decelerates. ${ }^{35}$ The capacity of PCP for super-efficiency/superexploitation will ensure it competes vigorously with both wage-work and capital-biased technology achieving scale economies.

More than ever before, the ILO's Decent Work needs to be a development objective (Nath 2008 quoting Rodgers 2001). It needs extension to all sectors of the informal economy. Less than ever before do the international and domestic political conditions suggest it is anything but a remote goal. 


\section{ACKNOWLEDGEMENTS}

This essay was originally developed in response to the inaugural conference of the EU CRIMPREV research network of criminologists, Universite de Louvain, Brussels in February 2007 (thanks to Joanna Shapland). An earlier version of the start of the theoretical part of this essay has now been published as 'Informal Capitalism, Social Order, Agency and Deviance' in Underground Economy: A Constant Companion (ICFAI Press 2008). It was further stimulated at the WIEGO workshop on the Informal Economy in China and India, Harvard University, April 2007; the Conference of Heterodox Economics, Bristol July 2007; a lecture at Rajiv Gandhi University, Itanagar, Arunachal Pradesh, in October 2007 and a keynote presentation at the ESRC conference on 'Rethinking Economic Anthropology', LSE/Goldsmiths College, London, January 2008 (thanks to Marty Chen, Sarah Cook, Pritam Singh, Vandana Upadhyay and the organizing team at LSE and Goldsmiths). It has been revised and developed in the light of the September 2008 workshop on 'Globalization and Labour: China and India' organized at UNBC by Paul Bowles and John Harriss, to the participants at which I am grateful. Thanks especially to Rohini Hensman, Colin Leys, Aseem Prakash and two anonymous reviewers for their constructive criticisms of the revised draft. The usual disclaimers apply.

\section{NOTES}

${ }^{1}$ See the review in Lerche, 2010.

2 There is a large literature in European economic history concerned with the phenomenon of 'proto-industrialization' where the debates revolve around the causal relation of PCP to factory production, rural-urban relations, multiple organizational pathways to industrialization, non-factory forms of industrialization and the co-existence of a variety of forms of production (Mendels 1972, Berg et al 1983). Tilly's coverage of Europe requires a lexicon for PCP: out-servants, cottagers, artisans, handicraft workers, petty trades, non-agricultural trades and crafts which have varied relationships to merchants' or commercial capital which he doesn't pursue (Tilly 1983: 5-12). That the period of this historical debate stops at 1900 again suggests that small scale enterprise is no longer of much importance in the modern economy.

${ }^{3}$ Despite resistance from the National Commission for Enterprises in the Unorganized Sector $(2006,2008)$, the concept accepted in official India - 'unorganized' rather than informal - also strongly suggests a disorder to be replaced by a different sets of arrangements governed by state planning. The official definition of being unorganized is a firm with electricity and fewer than 10 workers, which also shows no appreciation for the differences between PCPT and petty capitalism.

${ }^{4}$ Some of these factors were also invoked as forces that would undermine capitalism itself.

${ }^{5}$ By implication Khan is also challenging Hernando de Soto and new institutional economists such as AJR (Acemoglu, Johnson and Robinson) for all of whom well defined property rights are fundamental institutional preconditions for 'development'. 
${ }^{6}$ Other notable features not discussed in this essay include lack of legal or social protection and vulnerability (Kannan 2008: 5-8; see also Harriss-White, forthcoming).

${ }^{7}$ Combinations of these forces may operate at a given time and place, and it would be very difficult systematically to test any one of the relationships between the state's ambivalence, contradictions and selective failure to enforce its procedure on the one hand and the flourishing of self-employment, family firms and small enterprise on the other.

${ }^{8}$ The NCEUS 'struggles to bring the informal economy to the policy agenda' (Papola 2008: 6).

${ }_{9}^{9}$ We know from Eastern Europe and Russia as well as from India that in societies with pervasive corruption, the law abider is the 'deviant' and may actually be punished - as may those who refuse to punish the 'deviant' (Varese 2000, Ledeneva and Kurkchiyan 2000).

${ }^{10}$ Kate Meagher, working on Nigeria's informal economy, calls their study identity economics' (2004).

${ }^{11}$ Harriss-White, 2003.

12 See also Kanbur and Jhabwala 2004: 293-297 and 311, Ghosh 2009, and Ghose, Majid and Ernst 2008, who corroborate this globally.

13 Auer and Jha 2008, Chatterjee 2008: 530, and see Huws and Dahlmann 2007 generally.

${ }^{14}$ In addition 'marginal work' and open unemployment have also increased significantly during the period 1999-2005, putting pressure on those with livelihoods (Auer and Jha 2008).

${ }^{15}$ See Roman 2008 (for saris); Singh and Sapra 2007 (for garments); Kapadia 1999 (for gems and rural industrialization generally in S. India). There are, of course, also many explanations for PCP that do not rely on its superiority to wage labour in task specific sequences; for example both may be used by employers for their flexible response to seasonality of demand in the non-farm economy (Singh and Sapra 2007: 82-84).

${ }^{16}$ See Harriss-White, Mishra and Updahyay 2009 for details.

${ }^{17}$ While all non-locals require formal inner line permits to enter, even local tribal people are disenfranchised from economic citizenship under customary law outside their own territories. See Harriss-White, Prakash and Mishra 2010.

${ }^{18}$ In a presentation at the conference 'Development, Freedom, Welfare' Cornell University and Institute of Human Development, New Delhi, December 2008.

${ }^{19}$ A process not without opposition at the federal and state levels.

${ }^{20}$ Respectively Bouchard 2008, Holland 2009, Soros 2008, Ackerman 2008, Edmund Phelps and Joseph Stiglitz, presented at 'Development, Freedom, Welfare', Cornell University and Institute of Human Development, New Delhi, December 2008.

${ }^{21}$ Gowan argues that the structure and dynamics of the financial system have changed dramatically during the era of globalization. It is characterized by the consolidation of what he calls the new Wall Street System involving the rise to prominence of money markets and their transformation into funders of speculative arbitrage and centralized, oligopolistic creators of asset-price bubbles (East European stock markets/ dot.com/coffee/cocoa/other newly securitized commodities - food/oil) which can eventually be burst without loss to them and which become the major element in their rents. The system also involved deposit-taking banks scaling up and transforming 
themselves into speculative proprietary traders in - and lenders for trading in - (future) financial assets and collateralized debt obligations (CDOs), the maximization of balance sheet expansion and of leverage, and the outgrowth of 'shadow banking' entirely unregulated, with London fuctioning as a Wall Street satellite for regulatory arbitrage. Thus the housing bubble was engineered, like others before it, by the Wall Street banks. It is this integrated structure which collapsed in 2007-8, triggered by the realization that 'the suppliers of credit funding...had no way of knowing how much of the CDO mountain was junk'. Lending and debt-fed consumption have now seized up (Gowan 2009).

${ }^{22}$ ADB, 2009.

${ }^{23}$ Ahluwalia, presented at 'Development, Freedom, Welfare' Cornell University and Institute of Human Development, New Delhi, December 2008.

${ }^{24}$ WIEGO 2009. WIEGO does not distinguish PCP from labour.

${ }^{25}$ ADB 2009: 6.

${ }^{26}$ The activist Aruna Roy predicts an upsurge in violence. Presented at 'Development, Freedom, Welfare' Cornell University and Institute of Human Development, New Delhi, December 2008.

${ }^{27}$ Respectively Banaji 1977, and Kannan 2008: 22.

${ }^{28}$ For which a legal template was adopted by central government as long ago as 1995 .

${ }^{29}$ The fault lines of the two bills concerned are agriculture and non agriculture, not PCP and labour. The pension age threshold (60 years) resists revising downwards to be appropriate for landless labourers and construction workers who are frequently worn out by their late thirties (Penny Vera Sanso, Pers Comm 2009).

30. The UN has constituted a task force headed by Joseph Stiglitz (members include Prabhat Patnaik, Miguel d'Escoto Brockmann and Francois Houtart Paez) to recommend reforms to the global financial system in face of looming recession. Despite internal variations in their analyses all members argue against the anti-state regulation ideology practiced by the leading capitalist economies. Most of these: France, Germany, China, US have responded by significant state investments in the economy.

31 In the absence of such coordination, national protectionism will trigger political conflicts.

${ }^{32}$ For instance, by Lord Meghnad Desai. Presented at 'Development, Freedom, Welfare' Cornell University and Institute of Human Development, New Delhi, December 2008.

33 See Breman 2006; and eds Breman, Guerin and Prakash 2009, for the discussion of neo-bonded labour, which involves money plus labour markets.

${ }^{34}$ ADB 2009: 8.

${ }^{35}$ ILO, 2009.

\section{REFERENCES}

Ackerman, F. (2008) 'The Economics of Collapsing Markets', Real-world Economics Review 48(6): 279-290. 
Asian Development Bank (2009) The Global Economic Crisis: Challenges for Developing Asia and ADB's Response. Manilla: Asian Development Bank.

Alagh, Y. (2008) 'India and the World', Plenary presentation, 'Development, Freedom, Welfare', Cornell University and Institute of Human Development, New Delhi, December 2008.

Auer, P. and Jha, P. (2008) 'Labour Market Reforms in India: Barking up the Wrong Tree?', plenary paper, Indian Society for Labour Economics, Golden Jubilee Conference, Giri Institute, Lucknow.

Banaji, J. (1977) 'Capitalist Domination and the Small Peasantry Deccan Districts in the late $19^{\text {th }}$ Century', Economic and Political Weekly 12(33/34): 1375-1404.

Basile, E. (2008) 'From Green Revolution to Industrial Dispersal: Informality and Flexibility in an Industrial District for Silk in Rural S. India' Paper to the ESRC Conference on Rethinking Economic Anthropology, Goldsmiths College, London University.

Basile, E. and Harriss-White, B. (2000) 'Corporatist Capitalism, Civil Society and the Politics of Accumulation in Small Town India', Working Paper 38, Queen Elizabeth House, Oxford. http://www.qeh.ox.ac.uk/research/wpadtion.html?jor_id=44

Basu K. (ed) 2004 India's Emerging Economy: Performance and Prospects in the 1990s and Beyond. Cambridge: MIT Press.

Berg, M., Hudson, P. and Sonenscher, M. (eds) (1983) Manufacturing in Town and Country Before the Factories. Ithaca: Cornell University Press.

Bouchaud, J.P. (2008) 'Economics Needs a Scientific Revolution', Real-world Economics Review 48(6): 291-292.

Braithwaite, V. (ed) (2003) Taxing Democracy. Aldershot: Ashgate Publishing.

Cadene, P. and Holmstrom, M. (eds) (1998) Decentralized Production in Indian Industrial Districts. New Delhi: Sage Publications.

Chatterjee, B. (2008) 'Globalization, Growth and Employment: An Analytical Enquiry', Indian Journal of Labour Economics 52(4): 517-532.

CLSA Asia-Pacific Market (2009) Triple A Weekly Economic Commentary 3(4): 1-9.

Cook, S. and Binford, L. (1986) 'Petty Commodity Production, Capital Accumulation and Peasant Differentiation: Lenin and Chayanov in Rural Mexico', Review of Radical Political Economy 18(4): 1-31. 
EPW Research Foundation (2009) 'Stimulus Packages Facing Institutional Constraints', Economic and Political Weekly 44(4): 23-9.

Ghose, A. K. (2008) 'Globalization and Employment in Developing Countries', Indian Journal of Labour Economics 52(4): 497-504.

Ghose, A.K., Majid, N. and Ernst, C. (2008) The Global Employment Challenge. Geneva: International Labour Office.

Ghosh, J. (2009) 'The Outcry is Muted but the Food Crisis is Getting Worse' The Guardian, 9 January 2009, pp. 34.

Gowan, P. (2009) 'Crisis in the Heartland', New Left Review 55: 5-29.

Government of India (2007) Trend and Progress of Banking in India. Mumbai: Reserve Bank of India.

Government of India (2008a) Financial Sector Reforms. New Delhi: Planning Commission.

Government of India (2008b) Memorandum on the Financial Crisis. New Delhi:

Ministry of Finance.

Government of India (2009) Report on Effect of Economic Slowdown on Employment in India. Chandigarh: Ministry of Labour and Employment, Labour Bureau.

Harriss-White, B. (ed) 2002 Globalization and Insecurity. London: Palgrave.

Harriss-White, B. 2003 India Working. Ithaca: Cornell University Press.

Harriss-White, B. 'Work and Wellbeing in Informal Economies: The Regulative Roles of Institutions of Identity and the State', forthcoming in World Development.

Harriss-White, B., Mishra, D. and Upadhyay, V. (2009) 'Institutional Diversity and Capitalist Transition: The Political Economy of Agrarian Change in Arunachal Pradesh', Journal of Agrarian Change 9(4): 230-66.

Harriss-White, B., Prakash, A. and Mishra, D. (2010) 'Globalization, Economic Citizenship and India's Inclusive Developmentalism', Workshop on Citizenship, Heidelberg University, South Asia Institute.

Harriss-White, B. and Sinha, A. (2007) 'Introduction' in B. Harriss-White and A. Sinha, Trade Liberalization and India's Informal Economy (pp. 1-14). New Delhi: Oxford University Press. 
Harriss-White, B. and Sinha, A. (eds) (2007) Trade Liberalization and India's Informal Economy. New Delhi: Oxford University Press.

Holland, S. (2009) 'The World After Keynes', Red Pepper 163: 22-24.

Huws, U. (2003) The Making of the Cybertariat. London: Merlin.

Huws, U. (2007) 'The Emergence of Emergence: The Challenge of Designed New Research on the New International Division of Labour', Work Organization, Labour and Globalization 1(2): 20-35.

Huws, U. and Dahlmann, S. (2007) 'Global Restructuring of Value Chains and Class Issues', Proceedings of the ISA conference Work and Employment: New Challenges, Montreal, August 2007.

International Labour Organization (2009) Global Employment Trends. Geneva: ILO.

Jhabvala, R. and Kanbur, R. (2004) 'Globalization and Economic Reform as Seen From the Ground: SEWA's Experience in India', in K. Basu, India's Emerging Economy: Performance and Prospects in the 1990s and Beyond (pp. 293-312). Cambridge, MA: MIT Press.

Kannan, K.P. (2008) 'Dualism, Informality and Social Inequality Presidential Address', Indian Society for Labour Economics, Golden Jubilee Conference, Giri Institute, Lucknow.

Kapadia, K. (1999) 'Gender Ideology and the Formation of Rural Industrial Classes in South India Today’, Contributions to Indian Sociology 33(1-2): 329-52.

Kaplinsky, R. and Morris, M. (2000) A Handbook for Value Chain Research. IDRC/Institute of Development Studies, Sussex.

Khalidi, O. (2008) 'Hinduising India: Secularism in Practice', Third World Quarterly 29(8): 1545-1562.

Khan, M. (2003) 'State Failure in Developing Countries and Institutional Reform Strategies', ABCDE Paper, World Bank.

Kumar, A. (1991) India's Black Economy. New Delhi: Penguin.

Kumar, A. (2005) Black Economy in India. New Delhi: Penguin.

Ledeneva, A. and Kurkchiyan, M. (2000) Economic Crime in Russia. London: Kluwer Law International. 
Lerche, J. (2010) 'From "Rural labour" to "Classes of Labour": Class Fragmentation, Caste and Class Struggle at the Bottom of the Indian Labour Hierarchy', in B. HarrissWhite and J. Heyer, The Comparative Political Economy and Development: Africa and South Asia. London: Routledge.

Madan, T.N. (1987) 'Secularism in its Place', Journal of Asian Studies 46(4): 749-59.

McBarnet D. (2003) 'When Compliance is Not the Solution But the Problem: From Changes in Law to Changes in Attitude' in V. Braithwaite (ed), Taxing Democracy (pp. 229-243). Aldershot: Ashgate Publishing.

Meagher, K. (2004) 'Identity Economics: Informal Manufacturing and Social Networks in South-Eastern Nigeria', unpublished D. Phil. Thesis, Oxford University.

Mendels, F. (1972) 'Proto-industrialization: The First Phase of the Industrialization Process', Journal of Economic History 32(1): 241-61.

Mezzadri, A. (2008) 'The Rise of Neoliberal Globalization and the "New-old' Social Regulation of Labour: A Case of Delhi Garment Sector', Indian Journal of Labour Economics 51(4): 603-618.

Myrdal, G. (1968) Asian Drama. London: Penguin.

Nath G.B. (2008) 'Globalization and Growth of Precarious Jobs in the Indian Labour Market: Implication for Economic Policy’, Indian Journal of Labour Economics 52(4): 533-544.

National Commission for Enterprises in the Unorganized Sector (2006) Social Security for Marginalized Workers. New Delhi: NCEUS.

National Commission for Enterprises in the Unorganized Sector (2008) The Global Economic Crisis and the Informal Economy in India: Need for Urgent Measures and Fiscal Stimulus to Protect Incomes in the Informal Economy. New Delhi: NCEUS.

National Commission for Enterprises in the Unorganized Sector (2009) 'Growth Pole Programme for Unorganized Sector Enterprise Development'. New Delhi: NCEUS.

Neethi, P. (2008) 'Contract Work in the Organized Manufacturing Sector: A Disaggregated Analysis of Trends and Their Implications', Indian Journal of Labour Economics 52(4): 559-574.

Papola, T.S. (2008) Employment in Development: The Indian State and the ILO Agenda', plenary paper, Indian Society for Labour Economics, Golden Jubilee Conference, Giri Institute, Lucknow. 
Parry, J. (2007) 'Trade Union Politics in India', Marett Lecture, Exeter College, Oxford.

Patnaik, U. (2007) The Republic of Hunger and Other Essays. London: Merlin.

Roman, C. (2008) 'Learning to be Labour: Skills and Entry into Silk Clusters in India [title tbc]', unpublished D. Phil thesis, Oxford University.

Roy, R. (1996) 'State Failure: Political-Fiscal Implications of the Black Economy', Bulletin, Institute of Development Studies 27(2): 22-31.

Ruthven, O. (2008) 'Value and Values in a North Indian Value Chain', unpublished D. Phil Thesis, Oxford University.

Sardar, S.I. (2008) The Indian Experience of Globalization: An Overview', Regional Studies 26(3): 83-110.

Shapland, J. and Ponsaers, P. (2007) 'Deviance and Organized Crime in Europe's Informal Economy', Workpackage 5, CRIMPREV General Conference, Brussels, 2007.

Singh, N. and Sapra, M.K. (2007) Liberalization in Trade and Finance: India's Garment Sector', in B. Harriss-White and A. Sinha (eds) Trade Liberalization and India's Informal Economy (pp. 42-127). New Delhi: Oxford University Press.

Sinha, A., Sangeeta, N. and Siddiqui, K. (1999) The Impact of Alternative Policies on the Economy with Special Reference to the Informal Sector: A Multisectoral Study. New Delhi: National Council for Applied Economic Research.

Sinha A. and Adam, C. (2007) 'Modelling the Informal Economy in India: An Analysis of Trade Reforms' (eds) B. Harriss-White and A. Sinha, Trade Liberalization and India's Informal Economy (pp 307-64). New Delhi: Oxford University Press.

Soros, G. (2008) 'The Crisis and What to do About It', Real-world Economics Review 48: 312-318.

Stern, V. (2006) Creating Criminals: Prisons and People in a Market Society. London: Zed Press.

Tilly, C. (1983) Flows of Capital and Forms of Industry in Europe, 1500-1900. Ann Arbour: University of Michigan Centre for Research on Social Organization.

Unni, J. (2008) 'Women Workers in the New Economy', Indian Journal of Labour Economics 52(4): 657-674. 
Varese, F. (2000) 'Pervasive Corruption' in A. Ledeneva and M. Kurkchiyan (eds), Economic Crime in Russia (pp. 99-111). London: Kluwer Law International.

Vijay, G. (2008) 'De-fragmenting Approaches to the Global Disintegration of Value Creation: From Value Chains to Value Cycles', Department of Economics, University of Hyderabad.

Women in the Informal Economy Globalizing and Organizing (2009) 'Impact of the Global Recession on the Working Poor in the Informal Economy', http://wiego.org/about_ie/ie_news/EconomicCrises2009.php

\section{BIOGRAPHICAL NOTE}

Barbara Harriss-White is Professor of Development Studies at Oxford University and Director of Oxford's new Contemporary South Asian Studies Programme and the Master's in Contemporary India. She teaches and researches the Indian political economy. Recent books include Trade Liberalization and India's Informal Economy (OUP 2007), Defining Poverty in the Developing World (co-edited with Frances Stewart and Ruhi Saith) (Palgrave 2008), Rural Commercial Capital: Agricultural Markets in West Bengal (OUP 2008 - Edgar Graham Prize), and The Comparative Political Economy of Development: Africa and South Asia (edited with Judith Heyer) (Routledge 2010). 